DePauw University

Scholarly and Creative Work from DePauw University

9-30-2016

\title{
Studying like a Communist: Affect, the Party, and the Educational Limits to Capitalism
}

Derek R. Ford

DePauw University, derekford@depauw.edu

Follow this and additional works at: https://scholarship.depauw.edu/educ_facpubs

Part of the Education Commons

\section{Recommended Citation}

This is an Accepted Manuscript of an article published by Taylor \& Francis Group in Educational Philosophy and Theory on September 30, 2016, available online: http://dx.doi.org/10.1080/ 00131857.2016.1237347

This Article is brought to you for free and open access by the Education Studies at Scholarly and Creative Work from DePauw University. It has been accepted for inclusion in Education Studies Faculty publications by an authorized administrator of Scholarly and Creative Work from DePauw University. 


\title{
Studying like a communist: Affect, the Party, and the educational limits to capitalism
}

\author{
Derek R. Ford \\ DePauw University
}

In an effort to theorize educational logics that are oppositional to capitalism, this article explores what it means to study like a communist. I begin by drawing out the tight connection between learning and capitalism, demonstrating that education is not a subset but a motor of political-economic relations. Next, I turn to the concept of study, which is being developed as an educational alternative to learning. While studying represents an educational challenge to capitalism, I argue that there are political limitations to studying for which we need to account. Specifically, studying is not in itself political, but only represents the possibility of politics. To make this claim and to address these limitations, I turn to Jodi Dean's work on the communist Party. Dean posits the Party not as a master, director, or prophet, but as an infrastructure of affective intensity that maintains a gap in the order of things. I show that the Party is one way to organize and to defend study. Throughout the article, I illuminate the ways in which educational philosophers can contribute to political movement building by showing, developing, and refining the educational components of politics that many organizers and theorists neglect.

Keywords: Study, affect, communism, political education, Jodi Dean, learning society

\section{Introduction}

Within the abundance of educational literature on neoliberalism - most of which is concerned with issues of curriculum and policy - a provocative and insightful philosophical exploration has emerged concerning the educational logic of neoliberal capitalism. ${ }^{1}$ This conversation begins with the important observation that capitalism, as a social, economic, and biopolitical regime is legitimated and reproduced through the logic of learning. If we want to disrupt and combat capitalism, then, we need to not only understand the logic of learning, but also to formulate and enact alternative educational logics. Studying has been proposed as one such logic that is attracting the attention of educational philosophers (e.g., Ford, 2016a; 2016b; Harney \& Moten, 2013; Lewis, 2013; Rocha, 2015). This research has provided insights into the ways in which there are educational limits to capitalism. But, as I argue in this paper, it has not yet acknowledged the ways in which there are political limits to studying. In other words, the leap from alternative educational logic to oppositional educational logic has not yet been taken. The purpose of this article is to inaugurate this leap. More precisely, the problem that I identify is that studying, as heretofore theorized, only provides the opening for politics, and thus remains trapped in what Jodi Dean (2016) refers to as the "beautiful moment" of the crowd. To become a political force against capitalism, I contend, studying has to be theorized in relationship to political organization.

I begin this project by drawing out the connection between learning and capitalism, demonstrating why learning is so pivotal for the reproduction and maintenance of capitalism's hegemonic grip and, therefore, why it is an important target 
for developing counter-hegemonies. Seen in this light, education does not follow from but plays a key role in producing the political-economic order. I next move to an elaboration of studying, drawing primarily on the work of Tyson E. Lewis. Studying here is not positioned against learning writ large, but rather as a type of ellipses within learning, as an act that opens education up to the possibility that things might be radically otherwise. To draw out what I call the present political limits of study, I turn to Dean's recent book, Crowds and Party. Dean argues that the crowd event produces a discharge of equality that introduces a gap in the present order. Reading Dean through Lewis, I draw out how studying is the educational logic of the crowd. While the inauguration of the gap of possibility that the study of the crowd generates is necessary for politics, it is not sufficient. To back this up, I refer to two examples of radical study: hacking and Occupy Wall Street. Taken together, these examples reveal that because studying lacks direction and infrastructure, it can be reabsorbed within the dynamics of capital accumulation or cut short through state repression. Dean offers a corrective that I suggest educational philosophers should take seriously: the Party. For Dean, the Party is not a master, director, or prophet, but rather a type of affective infrastructure that maintains the gap of possibility and that, as I suggest, organizes and defends study, even in the direst and seemingly hopeless of circumstances.

\section{The educational limits to capitalism}

If capitalism is predicated upon the dispersion of learning throughout society, then the logic of learning represents a crucial educational limit to the reproduction of capitalist social, economic, and biopolitical relationships, or what I will collectively refer to as "production relations." Employing a Foucauldian analysis, Maarten Simons and Jan Masschelein (2008) have argued that the formation of a "learning apparatus" has been central to the rise of neoliberal governmentality. Governmentality refers to the tethering together of the state, the economy, and processes of subjectification. It is, in essence, "the field of action that compels the individual to act by facilitating an internalization (or subjectification) of rationalities or 'regimes of truth' that emanate from legal, health, or educational apparatuses of the state" (Pierce, 2013, p. 13). Governmentality weds together government and self-government, politics and subjectivity — and learning is the fulcrum.

Simons and Masschelein (2008) make four points to demonstrate the centrality of the learning apparatus in contemporary society. They first argue that learning has become the main engine of the economy, which is variously conceived of as the knowledge, information, or creative economy. Not only is education subjected to economics (which is what most critiques of neoliberalism focus on), but education itself is a "supplier" of the knowledge economy. Workers have knowledge, but they can always gain more knowledge. This leads to the second supporting claim, which concerns the emergence of "lifelong learning." Because of the constantly changing nature of the economy and society, we have to continually subject ourselves to learning in order to fit the needs of global capital and to continually attain happiness, satisfaction, and health. The school, on this model, teaches people how to learn so that they can enter adulthood, which is where one never stops learning. Moreover, adulthood - true, autonomous being - is defined by one taking responsibility for one's own learning, and this is the third aspect of the 
learning apparatus. "Learners," in this perspective, "should become the "managers' of their own learning, for example, by developing their own learning strategy, monitoring the process, and evaluating the results" (p. 400). The fourth point is that today the results of learning have to be employable. This is what "competencies" means today: they are the "outcome of learning and the input for the labor market and society" (p. 401). The state is able to withdraw from the management of society and any responsibilities toward the collective because there is no more collective; there is only an agglomeration of individual entrepreneurial selves who are free to learn and relearn, and who are solely responsible for their own lot in life.

Bringing Giorgio Agamben into the conversation, Lewis (2013) has identified the notion of potentiality at the center of neoliberal capitalism and as that which drives neoliberalism's logic of learning. Potentiality can be broken down into two types: generic and effective. Generic potentiality is the common meaning potentiality takes on, in which potentiality is the passage from potentiality to actuality, from the state of "I can" to the act of doing or being. Neoliberal capitalism and its logic of learning are "anchored in an ontology of generic potentiality as a 'not yet' that 'must be' made manifest in measurably determinate, socially useful, and economically manageable skill sets" (p. 6). Learning is defined by the achievement of a pre-determined end, which is why learning is always measureable and testable. Benchmarks are then established to chart one's progress along the way to a learning outcome, objective, or goal.

The irony of generic potentiality is that through the passage to actuality potentiality is destroyed: one is no longer in potential, one no longer can but is. Thus, we arrive at the other form of potential: effective potentiality, or potentiality freed from the actualization imperative. Effective potentiality is, therefore, the potential to be and not to be, to do and not to do. Whereas generic potentiality is a potentiality in relationship to a particular thing or act, effective potentiality as the potentiality to not-be is "a potentiality that has as its object potentiality itself" (Agamben, 1993/2007, p. 36). Potential is not actualized but preserved and held within itself. Potential stays impotential.

Agamben sees these two types of potentiality as radically separate, and in doing so, Lewis (2013), contends, he "takes for granted the existence of in-capabilities and propensities as the necessary background for the appearance of capabilities. He assumes that one can" (p. 45). Lewis, in turn, asserts a sort of dialectical relationship between them, which is why he writes of im-potentiality. To be im-potential is to be able to be and to be able to not be simultaneously, to experience potential freed from any predetermined category or identity. The learning society eliminates im-potential because it is "obsessed with the measure of what someone can do on order to fulfill a particular role within the economy," and this obsession with "assessment and verification of actualization is... a form of evil that destroys the students' freedom to not be" (Lewis, 2011, pp. 588-589). True freedom, that is, is not the freedom to be this or that, but the freedom to be or to not be this or that, and thus the freedom to be or to not be something else altogether. Neoliberalism forecloses this freedom, it can't tolerate it because it disrupts the demand for performativity and efficiency. Thus, Lewis looks to the freedom of im-potentiality to develop an alternative educational logic to learning: the logic(s) of studying.

Whereas learning is always concerned with and determined by ends (learning goals, outcomes, etc.), studying is about means: it is definitional of studying that when one engages in the act one does not have an end in mind. When one sets out to study 
there may be an end in sight (a dissertation or a book, or a piece of information or a theoretical development), but as one begins to study the end retreats. As Lewis (2014) puts it, "The studier prefers not to engage in self-actualization... constantly moving forward toward some kind of indeterminate goal while simultaneously withdrawing from the very idea of goals in the first place" (p. 164). When we wander in the archives, or when we follow link after link after link on the internet until we end up watching obscure YouTube videos, the ends of our project are distanced or, more accurately, they are suspended. In the learning society, such wandering is interpreted as procrastination. We tend of think of what is actually studying as getting distracted and sidetracked. The state of impotential has to be overcome as quickly as possible, and anything that interferes with this process is a hinderance. This interpretation follows directly from the obsession with actualizing potential and from the demand that learning contribute directly and immediately to the functioning of capitalism and to self-actualization.

Studying can't be properly said to "produce" works, for while studying surely contributes to a product, its contributions can't be delineated in any coherent way. Even with hindsight studying resists strict signification. Studying instead leaves "traces," and

Lewis identifies three of these traces that shed light on the logic of study. First, when studying one "prefers not to." "When deep in study and someone asks, "so what have you found out?' or 'so what is your stance on $x$ ?,' the studier prefers not to say, thus withholding conclusions" (p. 164). It is not that the studier will not say, in which case they would possess determinate knowledge that they refuse to share, and it is not that the studier cannot say, in which case they would lack any potential answer. Instead, the studier both can and cannot say. Second, studying takes place within the "no longer, not yet." When studying one is no longer ignorant but is not yet a master. Studying pushes toward and withdraws from the command of knowledge. Third, studying is organized around the "as not." While learning about an object or idea we engage that object or idea as it is, but while studying and object or idea we engage it as not. Lewis gives the example of studying a car engine by taking it apart. This act is indistinguishable from a mechanic taking apart a car engine for a certain goal and purpose. What distinguishes the two engagements with the engine is the fact that the studier of the engine engages the engine as not an engine. This frees the object up for unforeseen and unforeseeable uses; activities are divorced from predetermined purposes, and signs from predetermined significations.

Studying, it's important to note, is not necessarily the opposite of learning. "Studying," Lewis (2013) writes, "suspends ends yet does not retreat into pure potentiality. It is the ambiguous state of recessive sway that holds within itself this and that without choosing either" (p. 147). Again, Lewis' critique of Agamben is that he doesn't take into account the fact that learning is, in many ways, a presupposition to the act of study in that to be im-potential requires. Studying opens up what has been learned to the possibility of being otherwise, opening up ellipses within the learning society that can be stretched to render it inoperative.

\section{Crowd study and the beautiful moment}

Learning orders students according to existing identities and capabilities, grading them according to their ability to actualize sets of skills, knowlegdges, habits, and so on. 
Learners are graded and ranked, their ability to conform to predetermined commands is evaluated, and these evaluations subjectify the learner to corresponding economic, social, and political roles. Not everyone's potential is invested in, of course. Many are victims of quite violent disinvestment. One set of learners "can" and another set "cannot." The first set are tasked with becoming self-entrepreneurs, constantly learning and relearning to meet the constantly shifting global market society, and the latter set are subject variously to abandonment and repression. Studying interrupts the demand to actualize potential by introducing a hyphen in between potential and impotential, so that the slogan of the studier becomes "I can... I cannot." Studying is antagonistic to the learning regime and the neoliberal production relations it reproduces because it is incommensurable with the latter's obsession with ends and measurability. While studying one prefers not to be this or that category, this or that kind of worker, and capital accumulation and social progress are thrown into crisis.

One of the most important things that Lewis' theory of study does is reveal that education is not a subset of or subservient to politics and economics. His work helps us understand that forms of educational life do not follow from, but lie at the heart of, politics. Yet while studying is antagonistic to capitalism and its learning society, the manner in which this educational logic becomes a political force is underdeveloped at best, and debilitating at worst. To make this argument, I want to turn to the recent work of political and cultural theorist Jodi Dean, and in particular her book Crowds and Party. While Dean doesn't address education, learning, or studying, her insights nonetheless have important implications for the matter at hand, for not only revealing the limitations of studying as it has so far been theorized but, more importantly, for making studying into a political force.

Toward the end of her 2012 book, The Communist Horizon, Dean (2012) noted that "our political problem differs in a fundamental way from that of communists at the beginning of the twentieth century-we have to organize individuals; they had to organize masses" (196). Her new book begins here, with a theoretical and historical examination of this contemporary subject of politics: the individual. The individual subject-form leaves revolutionary politics fragmented and isolated, moving from local reform to local reform without articulating any grand vision. The prominence of individuality results from an assault on collectivity. One of the strange ways in which we embrace this assault is when we turn to "do-it-yourself" politics, which, Dean (2016) writes, "is so unceasing that 'taking care of oneself' appears as politically significant instead of a symptom of collective failure — we let the social safety new unravel — and economic contraction —in a viciously competitive job market we have no choice but to work on ourselves, constantly, just to keep up" (p. 31). Dean sets out to reclaim this collectivity.

She begins by reading Althusser's famous thesis on interpellation backwards, standing it right-side up. In Althusser's formulation, ideology interpellates individuals as subjects. He gives the example of a police officer shouting, "Hey, you there!" When one turns around in response to the hail, one is subjectified. Although, as Althusser repeatedly clarifies, one is always-already a subject. Even before one enters the world they are enmeshed within the familial, medical, legal, and other ideological apparatuses. Dean, on the contrary, contends that instead of interpellating the individual as a subject, ideology interpellates the subject as an individual. Rephrasing one of Althusser's arguments, she writes, "What do children learn in school? They learn that they are individuals" (p. 85). 
Viewing interpellation as an act of individuation poses the individual subject-form as a problem, as the result "of the enclosure of the common in never-ceasing efforts to repress, deny, and foreclose collective political subjectivity... Rather than natural or given, the individual form encloses into a singular bounded body collective bodies, ideas, affects, desires, and drives" (p. 80).

When we are individuated we are separated from collectivity, isolated, trapped in our fictional egos. Individuation, however, never works smoothly or totally, and the gaps created by its non-completion or consistent failure are where the subject is located. The gap is also the occasion of politics: "Political subjectivization involves forcing this nonidentity, making it felt as an effect of the subject" (p. 89). Dean refers to this as a split in the people, which includes not just the split between those who have and those who don't, or between the included and excluded, but a split within the people's consciousness, the ways in which we aren't fully presentable, transparent, or accountable to ourselves. Individualization, that is, always fails, and the crowd seizes on and amplifies this failure, forcing the people into the realm of what Lewis calls im-potentiality, that place of limbo between subjectificaiton and desubjectification. Group dynamics and crowd theory are important here, and in particular Gustave Le Bon and Freud. Le Bon, a conservative racist who had nothing but contempt for the revolutionary crowds in the industrial centers of the $19^{\text {th }}$ century, identifies four key characteristics of the crowd: "contagion, suggestion, affective intensification, and de-individualization" (p. 95). Freud, for his part, appropriated crowd theory and Le Bon's work to argue that the crowd is "a source of new feelings, thoughts, and ideas" as well as "the novel consistency of a provisional being" ( $p$. 100). To put it through two of Lewis' traces of study, we could say that in the crowd we experience ourselves as no longer ourselves but not quite an other self, and that we experience ourselves as not ourselves.

The no longer, not yet and as not of the crowd can bring into being what Elias Canetti called the crowd's egalitarian discharge. The density of beings in place ordains this libidinal excess, which liberates subjectivity from the individual subject form. The equality of the crowd's egalitarian discharge is thus not the equality of disparate individuals, but an equality flowing from the dissolution of the boundaries of the interpellated individual. The libidinal feeling of the egalitarian release enacts the affective dynamics of the crowd. Specifically, the desire of the crowd is to increase, expand, and endure, and it will do these things so long as it has a goal. "Direction," as Dean writes, "intensifies equality by providing a common goal. If the crowd is to continue to exist, the goal must remain unattained. Expressed in Lacanian terms: desire is a desire to desire" (pp. 122-123). This direction, of course, need not be explicit. In actuality, the direction of the crowd is usually quite uncertain. Quite often the direction of the crowd is formulated negatively, as an expression of anger and a desire to move away from some system, event, structure, etc. The crowd emerges from within the gap of subjectivity, engaging us in a process of joyful disindividuation that takes the form of an intense belonging. This discharge, in turn, pushes us to want more, and it enables us to experience the force of collectivity, accomplishing what we could not accomplish as single or even as aggregated individuals.

The crowd experience of collectivity and equality is enamoring. Resisting and breaking free from the enclosure of subjectivity and feeling the jouissance of desire can feel like liberation. Some radical activists_-Dean specifically calls out "autonomists, 
insurrectionists, anarchists, and libertarian communists" (p. 125)—organize to achieve precisely this "beautiful moment," and their political program revolves around sustaining the beautiful moment. This is not just a dangerous mistake, but a complete dead end, for the crowd is not political. Rather, the crowd offers an opening for politics by installing a gap in the order of things.

Here, it might be helpful to bring in another one of Althusser's (2006) ideas: the materialism of the encounter. Althusser begins his brilliant treatise simply: "It is raining," he writes. "Let this book therefore be, before all else, a book about ordinary rain" (p. 167). In the ordinary rain Althusser sees Epicurus' atoms flying parallel until there is what Epicurus called a clinamen, or swerve. With this swerve, atoms encounter other atoms, and the possibility of the new is produced. Yet it is only the possibility of the new, for the encounter, as Althusser insists, has to take hold, has to endure and persist. Generation takes place when the encounter is sustained, but there is nothing to guarantee whether or not an encounter will take place, whether or not it will hold, and in what direction it will go if it indeed does take hold. The encounter can thus take place, take hold, and take off. The sustained encounter and its results are always a bit of a surprise, which "is what strikes everyone so forcefully during the great commencements, turns or suspensions of history... when the dice are, as it were, thrown back on the table unexpectedly" (p. 196). In the crowd, people encounter one another, and as the boundaries between them dissolve, as subjectivity resists and escapes enclosure, the chance opens for new political arrangements and production relations. Yet, as Dean (2016) exhorts, this politics - this beautiful moment of encounter - isn't really politics, for "Politics combines the opening with direction, with the insertion of the crowd disruption into a sequence or process that pushes one way rather than another" (p. 125). The beautiful moment is when the encounter takes place, but what will ensure that the encounter will take hold and that it will take off in the right - or better, left—direction. Without paying attention to the matter of organization and affirmative direction, the crowd and its educational logic can be reabsorbed into the circuits of capitalist valorization, or worse, can work to strengthen the rule of capital. This brings us to the political limits of studying.

\section{The political limits to studying}

Studying is, like the crowd event, a beautiful moment of encounter, the opening up of the possible, the breeding ground of the new. While studying one is disindivuated, swaying between subjectification and desubjectification, between being this and being that. The studier resists classification, preferring not to actualize any predicate. And like the crowd event, I contend, studying isn't politics, it is only the occasion for politics, a necessary but insufficient educational logic for the struggle against capitalist production relations and for the common. Without something more, studying can retreat from impotentiality into impotence, and, on the other hand, it can be actualized into something reactionary. To illustrate these possibilities, I will turn to two examples.

The first example is of studying as hacking, when one takes some thing or process, enters into and disrupts it. Hacking is an intervention that directs something toward other ends and uses, detaching it from its attachments to other objects and processes, potentially opening it up to the unforeseen and unforeseeable. In this way, hacking is a transgression and the hacker is an outlaw, one who literally lives by transgressing the 
lawful order that dictates propriety (who can do what with what). Lewis and Friedrich (2016) bring up the Anonymous collective, which has "repurposed websites and servers to expose particular contradictions and injustices in the capitalist system" (p. 244). Not only their actions, but Anonymous' very mode of organization is subversive in that anyone can join. Membership in the collective is not predicated upon any particular identity or a commitment to a specific end. Anonymous are "pirates who steal back private code for common use, and in this sense open up the world of code to unanticipated mutations" (ibid.). One of Anonymous' first major actions was a swarm attack on the Church of Scientology for their efforts to censor online criticism of the Church. In addition to sending all-black faxes to their fax machines (to use up ink), Anonymous members coordinated a Google bomb attack by linking "scientology" to a host of other words, like "dangerous" and "cult," to influence (redirect) any Google searches for scientology. Through distributed denial-of-service attacks, in which multiple computers the infrastructure of root nameservers, Anonymous hackers have shut down a host of websites, from the Department of Justice (in response to the DoJ's takedown of a file-sharing network) to the International Association of Chiefs of Police (as part of a national day of action against police brutality).

While hacking is indeed a reappropriation of code and a repurposing of the networked infrastructure of contemporary capitalism, there is nothing inherently revolutionary about hacking. For as many Anonymous actions that have supported revolutionary political movements, there have been others that have arguably hindered such movements. Consider Anonymous' intervention in the "Arab Spring" uprisings as a case in point. Anonymous sought to support the uprisings by attacking government websites and publicizing the private information of government officials who were opposing or repressing the protests. Yet in addition to attacking the governments of Egypt and Tunisia, which were indeed repressing popular revolts, Anonymous also attacked the government of Syria, which was battling a range of forces, including those associated with al-Qaeda and its splinter group, Daesh, or the Islamic State in Syria. The situation in Syria was much different than in Egypt or Tunisia, as the government retained popular support and immediately engaged in a series of serious reforms, including the drafting of an entirely new constitution (see Glazebrook, 2013). Indeed, it could be said that in Syria the government was the progressive force. Or consider a spin-off of Anonymous, Ghost Squad, which shut down the official website of the Loyal White Knights of the Ku Klux Klan and the next week attacked the website of Black Lives Matter (before tweeting, "All lives matter!'). Regardless of one's position on these issues, conflicts, nation-states, and so on, it is clear from these few examples that hacking doesn't have a politics and that, as an act of studying, it is not inherently against capitalist production relations.

The second example that I turn to here is meant to illustrate the potential apolitical impotence of studying, and it brings us more directly into conversation with Dean. In the last chapter of Lewis' (2013) On Study, he turns to the early stages of the Occupy Wall Street movement to articulate the "im-potential political dimension to studying" (p. 150). Lewis celebrates the beginning stage of Occupy Wall Street as a form of collective, public studying, especially in its absence of concrete demands. While the mainstream press and politicians were anxious to hear what the protesters were demanding so they could issue a response accordingly, the occupation "spent most of its time preferring not to commit to any one demand over and above any other" (p. 152). Rather than actualize 
political polemics and demands, articulating them into proposals that could then be evaluated, occupiers produced a rupture within the received order of political struggle. The occupation actively resisted the drive to achieve results and instead conducted an ongoing study of politics, suspending the pursuit of measureable outcomes; engaging in protest as not protest. As a result, efforts to grade Occupy falter, for there were no preestablished criteria with which to evaluate it.

Occupy celebrated horizontalism, leaderlessness, inclusivity, and the absence of hierarchical structures. Neither an undifferentiated mass nor an agglomeration of individuals, the occupiers formed a

state of exception where dichotomies and divisions were left idle, the homeless the middle class, and a host of other intermediary grounds (including students) met in an atopic space and time to study the sublime art of discussing across differences and living across class divisions. What emerged was precisely the question (and not the answer) of inclusion and exclusion facing not only OWS but the contemporary learning society as such. (p. 159)

This state of exception was exemplified in the slogan, "We are the $99 \%$ !" The $99 \%$ was a kind of non-identity, "a totally generic yet absolutely irreducible singularity" (p. 157), as Lewis puts it. "We are the $99 \%$ !" took a quantity and transformed it into an indefinable quality, a way of grouping people without resorting to predicates and already-established identities. Just precisely who the $99 \%$ were (or are), was never fully delineated, couldn't quite be accounted for. The question was left open for collective study.

A major problem with this ongoing collective study, however, is that there was nothing to defend it or to sustain it. Capital and its state weren't studying, but were rather gearing up to unleash a wave of repression that would eventually undo the occupation. The Partnership for Civil Justice Fund has released several sets of documents obtained through Freedom of Information Act requests that detail the dense network of surveillance and repressive efforts that included offices of the Federal Bureau of Investigation, the Department of Homeland Security, the New York Stock Exchange, the Federal Reserve, universities and colleges, major corporations, local police forces, and local governments, as well as the Bureau of Alcohol, Tobacco, and Firearms and the U.S. Marshals Service (Partnership for Civil Justice Fund 2012; 2016). In this case, repression opened the door to reabsorption, as many Occupiers entered to non-profit industrial complex, or even started their own business ventures to profit from their activism.

Occupying and hacking represent study as embryonic political praxis, the enactment of educational logics that are potentially antagonistic to capitalist production relations and capital's logic of learning. Whereas capitalism demands that everythingeven that which opposes it - be actualized so that it can be subsumed within its circuits of productivity, occupying and hacking interrupt this seemingly ceaseless process, opening up the world and subjectivity to the possibility of being otherwise than. Studying is therefore, I proffer, the educational activity of the crowd, a way to pedagogically bring forth the beautiful moment. This is a crucial element of struggle but, as Dean insists, it isn't properly a politics; it is merely an opening for politics. Writing again explicitly about political movements, Dean (2016) writes: 
The beautiful in-between of infinite potentiality can't last forever. People get tired. Some want a little predictability, reliable food sources, shelter, and medical care. Others realize their doing all the work... The crowd isn't an alternative political arrangement; it's the opening to a process of re-arrangement. (p. 142)

The question, then, is how to seize upon this opening and carry it forward into a real revolutionary movement. How, in other words, to make the encounter take hold, how to make it take off in a desirable direction? These are questions that, while they should always be open to study, have to be answered, at least provisionally and contingently. Or else the market and its advertising agencies will come knocking with an endless list of glossy, high-definition answers. Or, alternatively, the state will come knocking down doors, guns drawn and handcuffs aplenty. The encounter won't take hold and the possibility of the new will be foreclosed as the crowd is dispersed through redirection, exhaustion, or repression.

\section{Studying like a communist}

We already have an answer-or, perhaps, the beginnings of an answer - to these questions: the organizational form of the Party. The crowd craves affirmative direction and it wants to persist, to spread, to keep the gap within the order of things open. This is precisely what the Party does. Hence, Dean proposes that the primary role of the Party is not that of the prophet, director, or master. Instead of providing answers and directions, the Party is, more than anything else, a type of affective infrastructure that maintains the gap of desire and, I would add, that sustains the practice of study.

To make this claim, Dean turns to the history of communist parties not where they were strongest - like in the Soviet Union or the People's Republic of China-but where they were weakest: the U.S. and Britain. In particular, she turns to Vivian Gornick's (1977) beautiful book about the experience of former members of the Communist Party of the USA, The Romance of American Communism. The book paints a portrait of the CPUSA as an apparatus that generated feelings of imagination and possibility, as an institutional configuration that, in the direst of circumstances, "held open a gap in the given through which people could see themselves in collective struggle changing the world" (Dean, 2016, p. 220). From the larger tasks (organizing workers and the unemployed, protests, campaigns, and jail support), to the seemingly smaller tasks (canvassing neighborhoods, organizing, facilitating and attending local meetings, selling newspapers, making and distributing leaflets, raising funds), all Party work was not just filled with a sense of purpose, immediacy, and enthusiasm, but served to generate these feelings. As Dean puts it, "It wasn't the vision that sustained the activity. The activity was the practical optimism that sustained the vision" (p. 228).

Stated differently, it wasn't that the Party's vision was out there, something external that had to be attained. Instead, the vision was internal, traversing the subject and the collective. As Paul Levinson, who was raised in a New York City housing project dominated by Communists in the early $20^{\text {th }}$ century, says:

...it was alive. Intense, absorbing, filled with a kind of comradeship I never against expect to know. In those basement clubrooms in The Coops, talking late 
into the night, every night for years, we literally felt we were making history. Do you know what I mean when I say that? We felt that what we thought and spoke and decided upon in those basement rooms in the Bronx was going to have an important effect on the entire world out there. (Gornick, 1977, p. 56)

The gap that the Party held open made it possible for members to study, to live within a world no longer bourgeois but not yet communist, to transform routine activities (talking, writing) into something profound and earthshaking. The world was not just thought of in these terms, it was experienced in them.

The Party perspective, then, was two-fold. On the one hand, there was classconsciousness, a learning of the tendencies and laws of capital accumulation and the dynamics of imperialism, racism, and national oppression. On the other hand, however, was an affective intensity that things can be otherwise and that this otherwise is already present, already germinating. "The perspective," Dean (2016) says, "is like a law, the law enabling communist desire, setting it apart from the capitalist world by holding up and uniting the experiences of the oppressed." This law isn't external, however: "It's a law communist give themselves in order to hold themselves together when everything conspires to pull them apart - police repression, fear and paranoia, individual desire and need" (p. 243).

The only trace of study that seems to be absent in the Party is that of preferring not. After all, the perspective of the party is proletarian, and its members emphatically embrace and occupy this identity category. I want to propose that the Party occupies a contradictory position in relation to preferring not. On the one hand, preferring not is a fundamental feature of the crowd from which it emerges. This is most evident in the crowd's desire to desire, the requirement that the crowd's wish be forever unfulfilled. The crowd wants to endure, and this endurance depends, in part, upon its unmet desire. Here, Lewis provides the Party with a preparatory pedagogy, for the act of preferring not is, in lieu or in addition to the crowd event, what helps the student imagine the world beyond capitalism. Yet on the other hand, the Party serves to orient the crowd, giving it direction, ensuring that it doesn't get reabsorbed into the circuits of capital or redirected toward reactionary ends. It may be the case that the Party is forced to disavow its origins. This is a question that I leave open for further study.

When engaging in political dialogue and action, it is not uncommon to hear educational terms thrown around. We talk about testing our ideas in practice and about learning from our history. We form study groups. We question and revise our methods of facilitating meetings and of interacting with others. Politics is deeply educational. At the same time, the educational components of political movement building are rarely investigated in any rigorous manner. One of the most important contributions that educational philosophy can offer radical politics is this investigation. We can develop the tools, concepts, frameworks, and languages with which to understand contemporary political educational processes, and with which to construct and enact alternative and oppositional processes. In order to do this, however, we ourselves have to take up the perspective of the Party, the dual commitment to the proletarian position and to holding open the gap in the order of things.

\section{References}


Agamben, G. (1993/2007). The coming community, trans. M. Hardt. Minneapolis and London: University of Minnesota Press.

Althusser, L. (2006). Philosophy of the encounter: Later writings, 1978-87, ed. by F. Matheron and O. Corpet, trans. by G.M. Goshgarian. London and New York: Verso.

Dean, J. (2012). The communist horizon. London and New York: Verso.

Dean, J. (2016). Crowds and party. London and New York: Verso.

Ford, D. (2016a). A pedagogy for space: Teaching, learning, and studying in the Baltimore Rebellion. Policy Futures in Education, 14(2), 176-193.

Ford, D. (2016b). Communist study: Education for the commons. Lanham: Lexington Books.

Glazebrook, D. (2013). Divide and ruin: The west's imperial strategy in an age of crisis. San Francisco: Liberation Media.

Gornick, V. (1977). The romance of American communism. New York: Basic Books.

Harney, S., \& Moten, F. (2013). The undercommons: Fugitive planning and Black study. New York: Autonomedia.

Lewis, T.E. (2011). Rethinking the learning society: Giorgio Agamben on studying, stupidity, and impotence. Studies in Philosophy and Education, 30(6), 585-599.

Lewis, T.E. (2013). On study: Giorgio Agamben and educational potentiality. New York and London: Routledge.

Lewis, T.E. (2014). The fundamental ontology of study. Educational Theory, 64(2), 163178.

Lewis, T.E., \& Friedrich, D. (2016). Educational states of suspension. Educational Philosophy and Theory, 48(3), 237-250.

Malott, C.S., \& Ford, D.R. (2015). Marx, capital, and education: Towards a critical pedagogy of becoming. New York: Peter Lang.

Partnership for Civil Justice Fund. (2012). "Homeland security documents show massive nationwide monitoring of occupy movement). Retrieved 21 May 2016 from: http://www.justiceonline.org/dhs_releases_more_documents.

Partnership for Civil Justice Fund. (2016). "Exposed: ATF spying on Occupy and 'known anarchists and protesters' list. Retrieved 21 May 2016 from: http://www.justiceonline.org/exposed_aft_s_monitoring_of_occupy_and_known_ anarchists_and_protesters.

Pierce, C. (2013). Education in the age of biocapitalism: Optimizing educational life for a flat world. New York: Palgrave Macmillon.

Rocha, S. (2015). Folk phenomenology: Education, study, and the human person. Eugene: Wipf \& Stock.

Simons, M., \& Masschelein, J. (2008). The governmentalization of learning and the assemblage of a learning apparatus. Educational Theory, 58(4), 391-415).

\footnotetext{
${ }^{1}$ Most educational literature refers to "neoliberalism" or "neoliberal capitalism." While there is some value in this term, I prefer to speak of capitalism for three related reasons. First, there is a tendency to write about neoliberalism without explaining what neoliberalism is, which can lead to a good deal of confusion and misunderstanding. Second, neoliberalism must always be seen as a particular manifestation of capitalism.
} 
And third, neoliberalism is but one facet of the contemporary capitalist order, and paying exclusive attention to it distracts us from the broader picture (see Malott \& Ford, 2015). When drawing on particular authors, however, I honor their word choice. 